\title{
PERSELISIHAN DAN PERTENGKARAN SEBAGAI ALASAN PERCERAIAN DI PENGADILAN AGAMA
}

\author{
Eka Susylawati \\ (Dosen Tetap Jurusan Syari'ah STAIN Pamekasan)
}

\begin{abstract}
Abstrak:
Salah satu alasan yang sering dijadikan dalil oleh suami dan/atau isteri ketika mengajukan perceraian adalah bahwa antara keduanya terus menerus terjadi perselisihan dan pertengkaran serta tidak ada harapan untuk hidup rukun lagi dalam rumah tangga. Hal ini disebabkan ketika suami dan/atau isteri berkeinginan untuk bercerai, tetapi tidak memiliki dalil yang cukup, maka alasan perselisihan dan pertengkaran selalu dapat dipergunakan. Di pengadilan agama, alasan tersebut lazim disebut dengan syiqâq. Dalam Pasal 76 ayat 1 Undang-undang Nomor 7 Tahun 1989 dinyatakan bahwa dalam perkara syiqâq sebelum hakim memutuskan perkara perceraian, haruslah terlebih dahulu mendengar keterangan dari keluarga atau orang-orang terdekat dan dapat pula mengangkat hakam yang bertindak sebagai arbitrator. Praktik di pengadilan agama, pengangkatan hakam jarang dilakukan, karena pengadilan lebih sering mencukupkan pada kesaksian dari keluarga atau kerabat terdekat. Alasan lain adalah bahwa dengan kehadiran hakam, biasanya akan membuat proses penyelesaian perkara memerlukan waktu yang relatif lama, jika dibandingkan dengan tidak adanya hakam.
\end{abstract}

Kata Kunci :

syiqâq, perceraian, dan pengadilan agama.

\section{Pendahuluan}

Sebagai makhluk sosial, manusia selalu hidup berkelompok baik dalam kelompok terbesar, yang dikenal sebagai negara, maupun dalam kelompok terkecil, yaitu keluarga. Keluarga merupakan unit 
terkecil yang dibentuk melalui perkawinan, ${ }^{1}$ di mana perkawinan itu sendiri, salah satu tujuannya, adalah mempersatukan seorang lakilaki dan seorang perempuan dalam sebuah ikatan suami istri. Dengan ikatan perkawinan tersebut suami isteri saling membantu dan saling melengkapi agar masing-masing dapat mengembangkan kerukunan demi tercapainya kesejahteraan spiritual dan material dalam suasana kasih dan sayang. ${ }^{2}$

Untuk mengatur perkawinan di masyarakat sangat dibutuhkan adanya tata tertib dan kaidah-kaidah, yang lazim disebut dengan hukum perkawinan. Di Indonesia kaidah-kaidah tersebut telah dirumuskan dalam suatu undang-undang, yakni UndangUndang Nomor 1 Tahun 1974. dalam pasal 1 undang-undang tersebut dinyatakan bahwa perkawinan ialah ikatan lahir batin antara seorang pria dan seorang wanita sebagai suami isteri dengan tujuan membentuk keluarga (rumah tangga) yang bahagia dan kekal berdasarkan Ketuhanan Yang Maha Esa. ${ }^{3}$

Pasal 1 Undang-Undang Nomor 1 Tahun 1974 tersebut, diperkuat lagi dengan pasal 2 Kompilasi Hukum Islam (KHI), yang menyatakan bahwa pernikahan merupakan akad yang sangat kuat atau mitsâqan ghalîdlan untuk mentaati perintah Allâh dan ketika dilaksanakan merupakan ibâdah. ${ }^{4}$ Dari kedua pasal tersebut dapat dinyatakan bahwa perkawinan mempunyai hubungan yang erat dengan agama dan kerohanian. ${ }^{5}$

Yang dimaksud dengan ikatan lahir batin, sebagaimana disebutkan di atas, adalah ikatan yang tidak hanya cukup dengan

1Secara umum, perkawinan didefinisikan sebagai perjanjian untuk mensahkan hubungan kelamin antara seorang pria dengan seorang wanita untuk melanjutkan perkawinan. Ia juga dimaknai sebagai akad yang menimbulkan akibat hukum berupa halalnya melakukan persetubuhan antara laki-laki dengan perempuan, saling tolongmenolong serta menimbulkan hak dan kewajiban. Lihat R. Soetojo Prawirohamidjojo, Pluralisme Dalam Perundang-Undangan Perkawinan di Indonesia (Surabaya : Airlangga University Press, 1986) hlm. 27 dan Amir Nuruddin dan Azhari Akmal Tarigan, Hukum Perdata Islam di Indonesia (Jakarta: Prenada Media, 2004) hlm 39.

2 Lihat al-Qur'ân Surat al-Rûm (30): 21.

3 R. Subekti dan R. Tjintrosudibio, Kitab Undang-undang Hukum Perdata (Jakarta: Pradnya Paramita, 1999), hlm. 537.

4 Afdol, Penerapan Hukum Waris secara Adil (Surabaya: Airlangga University Press, 2003), hlm. 252.

${ }^{5}$ Nuruddin, dan Tarigan, Hukum Perdata, hlm. 43 
ikatan lahir saja atau batin saja, akan tetapi keduanya harus dipadu secara erat. Suatu ikatan lahir merupakan ikatan yang dapat dilihat dan mengisyaratkan bahwa hubungan hukum antara seorang pria dan wanita untuk hidup bersama sebagai suami isteri, dapat dikategorikan sebagai hubungan yang formal. Hubungan formal ini sangat nyata, sehingga dirasakan oleh suami isteri maupun pihak ketiga. Sebaliknya ikatan batin adalah ikatan yang tidak tampak dan hanya dapat dirasakan oleh suami dan isteri. Ikatan batin inilah yang dapat dijadikan dasar fundamental dalam membentuk dan membina keluarga yang bahagia. ${ }^{6}$ Dengan demikian, akad perkawinan dalam hukum Islam bukanlah perkara perdata semata,7 malainkan ikatan suci (mitsâqan ghalîdzan) yang terkait dengan keyakinan dan keimanan kepada Allâh.

Namun, seringkali tujuan yang ingin dicapai dalam sebuah perkawinan kandas di tengah jalan sehingga ikatan perkawinan harus terputus. Salah satu yang alasan memutuskan perkawinan yang paling sering terjadi adalah karena terjadinya perceraian antara suami isteri. Ini dikarenakan dalam kehidupan sehari-hari tidak semua orang dapat memahami, memaknai, menghayati, dan mengaktualisasikan pesan-pesan suci perkawinan itu sebagai suatu sunnatullâh yang idealnya diupayakan dijaga keberlangsungannya. ${ }^{8}$

\section{Alasan-alasan Perceraian}

Pasal 1 Undang-undang Nomor 1 Tahun 1974 menyatakan bahwa idealnya perkawinan yang dilakukan bersifat kekal, namun dalam perjalanan selanjutnya perkawinan yang telah dibina oleh pasangan suami isteri terkadang harus terputus. Putusnya perkawinan tersebut disebabkan oleh beberapa hal, yaitu: (1)

\footnotetext{
6 Prawirohamidjojo, Pluralisme dalam Perundang-Undangan Perkawinan, hlm. 38

${ }^{7}$ Hal ini berbeda dengan Hukum Perdata Barat (Burgelijk Wetboek), yang memandang perkawinan hanya sebatas hubungan keperdataan saja. Maksudnya adalah bahwa undang-undang tidak akan turut campur dalam upacara-upacara yang diadakan di gereja. Yang terpenting, perkawinan tersebut harus dilangsungkan di hadapan seorang pegawai pencatat sipil. Lihat Vollmar, Pengantar Studi Hukum Perdata (Jakarta: RajaGrafindo Persada, 1996), hlm. 50.

8 Siti Musawamah dan Moh Hasan, Cerai Gugat di Pengadilan Agama Pamekasan, (Pamekasan: Penelitian Kolektif, Stain Pamekasan, 2005), tidak diterbitkan, hlm 2.
} 
kematian salah satu pihak, (2) perceraian, dan (3) atas putusan pengadilan. ${ }^{9}$

Putusnya perkawinan karena kematian adalah berakhirnya perkawinan yang disebabkan salah satu pihak, yaitu suami atau isteri meninggal dunia. Putusnya perkawinan dengan sebab perceraian merupakan penghapusan perkawinan dengan putusan hakim atau tuntutan salah satu pihak dalam suatu perkawinan. ${ }^{10}$ Sedangkan yang terjadi karena putusan pengadilan, misalnya pembatalan perkawinan, yang menyebabkan perkawinan yang sebelumnya sah di mata hukum, dengan pembatalan tersebut, perkawinan dianggap tidak pernah terjadi.

Perceraian merupakan salah satu sebab bubarnya suatu perkawinan, sebagaimana diatur dalam Undang-Undang Nomor 1 Tahun 1974, dewasa ini mudah terjadi di masyarakat. Sering terdengar adanya tindakan sewenang-wenang dari pihak laki-laki, sehingga angka perceraian yang diajukan oleh pihak isteri (cerai gugat) semakin tahun semakin meningkat jumlahnya.

Sebenarnya Undang-undang Nomor 1 Tahun 1974 tidak mempermudah perceraian tanpa alasan yang dapat diterima, sebagaimana tampak dari tujuan perkawinan di atas. Namun demikian, dalam praktiknya justru terjadi hal yang sebaliknya, di mana terkadang seorang isteri dengan hanya alasan tidak dapat hidup bersama lagi, begitu mudah meminta cerai kepada suaminya. Di sisi lain seorang suami begitu mudah untuk menceraikan isterinya hanya dengan alasan tidak senang lagi. Untuk memperkecil dan mempersulit perceraian, undang-undang telah memberikan batasanbatasan dalam mengajukan perceraian, yakni harus cukup alasan dan melalui pengadilan. ${ }^{11}$

Dalam penjelasan pasal 39 Undang-undang Nomor 1 Tahun 1974 dan pasal 110 Kompilasi Hukum Islam disebutkan tentang alasan-alasan yang diajukan oleh suami atau isteri untuk menjatuhkan talak atau gugatan perceraian ke pengadilan. Alasanalasan itu adalah: Pertama, salah satu pihak berbuat zina atau menjadi

\footnotetext{
${ }^{9}$ Salim, Pengantar Hukum Perdata Tertulis (BW), (Jakarta : Sinar Grafika, 2005) hlm. 76

10 Subekti, Pokok-Pokok Hukum Perdata (Jakarta : Intermasa, 1995) hlm. 42.

11 Pengadilan yang dimaksud, bagi yang beragama Islam, perceraiannya diperiksa dan diputus di pengadilan agama. Sebaliknya, bagi yang non Islam dilakukan di pengadilan negeri.
} 
pemabuk, pemadat, penjudi, dan lain sebagainya yang sukar disembuhkan. Kedua peraturan tersebut tidak memberikan pernafsiran secara khusus tentang definisi zina. Namun pengertian zina dalam konteks perceraian harus diartikan secara sempit, yakni dalam pengertian overspel,12 yang berarti persetubuhan yang dilakukan antara seorang pria dan seorang wanita, di mana salah satu atau keduanya masih terikat dalam perkawinan yang sah. Dengan demikian, persetubuhan yang dilakukan antara seorang jejaka dan seorang gadis ataupun hubungan antara seorang duda dengan seorang janda tidak termasuk zina, sebagaimana alasan perceraian di atas. Sedangkan pemabuk, pemadat, dan penjudi dapat dijadikan sebagai alasan perceraian, jika perbuatan tersebut dilakukan secara berulang-ulang dalam jangka waktu yang relatif lama, sehingga dapat dikategorikan sulit untuk disembuhkan.

Kedua, salah satu meninggalkan pihak lain selama 2 (dua) tahun berturut-turut tanpa izin pihak lain dan tanpa alasan yang sah atau karena hal lain di luar kemampuannya. Dalam keadaan normal, pasangan suami isteri berdomisili dalam sebuah rumah yang sama. Apabila salah seorang dari suami isteri meninggalkan rumah tanpa alasan yang sah dan telah pindah ke rumah atau kota lain, maka ia telah meninggalkan pihak yang lain dalam pengertian seperti alasan perceraian di atas. Jangka waktu yang diberikan oleh undang-undang adalah minimal 2 (dua) tahun, dan pihak yang meninggalkan tidak secara sungguh-sungguh untuk kembali. Namun, apabila ia pada awalnya meninggalkan dengan alasan yang sah, maka jangka waktu 2 (dua) tahun tersebut dihitung mulai saat alasan sah tersebut tidak ada lagi. Jika ditafsirkan secara a contrario, maka jika ia meninggalkan rumah kurang dari jangka waktu tersebut, maka hal yang demikian tidak dapat dijadikan sebagai alasan perceraian.

Ketiga, salah satu mendapat hukuman penjara 5 (lima) tahun atau hukuman yang berat setelah perkawinan berlangsung. Alasan perceraian yang ketiga ini dapat dijadikan sebagai alasan perceraian, jika hukuman/pidana tersebut diputuskan oleh hakim. Namun jika pidana tersebut dijatuhkan sebelum terjadi perkawinan, maka alasan tersebut tidak dapat dipergunakan, karena dianggap telah diketahui oleh pihak yang lain.

12 Prawirohamidjojo, Pluralisme dalam Perundang-Undangan Perkawinan, hlm. 128. 
Keempat, salah satu pihak melakukan kekejaman atau penganiayaan berat yang membahayakan pihak yang lain. Dalam penjelasan Undang-undang Nomor 1 Tahun 1974 maupun dalam Peraturan Pemerintah Nomor 9 Tahun 1975, tidak ada penjelasan tentang maksud dari istilah kekejaman atau penganiayaan berat. Akibatnya, penafsiran terhadap alasan ini diserahkan kepada hakim. Namun idealnya hakim memutuskan suatu perceraian dengan alasan tersebut, jika perbuatan yang dilakukan oleh salah satu pihak menimbulkan cacat, luka-luka, atau setidak-tidaknya merugikan kesehatan.

Kelima, salah satu pihak mendapat cacat badan atau penyakit yang berakibat tidak dapat menjalankan kewajibannya sebagai suami isteri. Namun demikian, tidak semua cacat badan atau penyakit dapat dijadikan alasan untuk bercerai, karena hanya penyakit dan cacat yang mengakibatkan suami isteri tidak dapat melakukan kewajiban-kewajiban dalam hidup berumah tangga, misalnya sakit ingatan, lumpuh dan sebagainya, yang dapat dikategorikan sebagai mendapat cacat badan atau penyakit. apabila dipandang perlu, sebelum memutuskan hakim harus memperoleh pertimbangan dari dokter.

Keenam, antara suami isteri terus-menerus terjadi perselisihan dan pertengkaran yang tidak ada harapan lagi untuk hidup rukun dalam membina rumah tangga. Alasan perselisihan dan pertengkaran yang terus menerus antara suami isteri, merupakan alasan klasik yang sering dipergunakan dan sepintas lalu merupakan alasan yang paling mudah untuk dipergunakan sebagai alasan perceraian. Hal ini disebabkan jika suami dan/atau isteri ingin bercerai, namun tidak menemukan alasan-alasan sebagaimana telah diuraikan sebelumnya, maka dapat menjadikan alasan perselisihan dan pertengkaran tersebut untuk bercerai. Akibatnya, alasan ini disebut sebagai alasan yang ngaret karena selalu dapat dijadikan dalil untuk bercerai, walaupun mungkin dalam praktiknya alasan ini bisa dibuat-buat oleh pihak yang menginginkan perceraian.

Ketujuh, suami melanggar ta'liq thalaq. Pada umumnya ta'liq thalaq diucapkan oleh suami, sehingga seolah-olah ia merupakan kewajiban suami. Tujuan dari ta'liq thalaq adalah untuk melindungi isteri dari tindakan sewenang-wenang suami. Jika terjadi pelanggaran ta'liq thalaq yang pernah diucapkan oleh suami, apabila isteri tidak 
rela atas perlakuan suami, maka isteri dapat mengajukan gugatan perceraian dengan alasan terjadi pelanggaran terhadap janji yang telah disepakati.

Kedelapan, pindah agama atau murtad yang menyebabkan ketidakrukunan dalam rumah tangga. Perbedaan agama suami isteri dapat menyebabkan ketidakharmonisan rumah tangga, sehingga jika suami atau isteri pindah agama setelah perkawinan terjadi, maka salah satu pihak dapat mengajukan perceraian.

\section{Perselisihan dan Pertengkaran (Syiqâq) sebagai Alasan Perceraian}

Alasan klasik yang sering dijadikan dasar perceraian di pengadilan agama adalah suami dan isteri terus-menerus terjadi perselisihan dan pertengkaran yang tidak ada harapan lagi untuk hidup rukun dalam membina rumah tangga. Hal ini dapat dibuktikan dari prosentase jumlah perceraian di sebagian besar pengadilan agama dengan menggunakan alasan tersebut.

Perkara perceraian hanya dapat dilakukan di depan sidang pengadilan setelah pengadilan tidak berhasil mendamaikan kedua belah pihak, serta cukup alasan bagi mereka untuk bercerai sehingga tidak ada lagi harapan untuk hidup rukun dalam membina rumah tangga atau perkawinan mereka betul-betul tidak dapat dipertahankan lagi.

Dalam praktik di pengadilan agama, alasan perceraian sebagaimana tersebut dalam pasal 19 huruf f Peraturan Pemerintah Nomor 9 Tahun 1975, yakni terus-menerus terjadi perselisihan dan pertengkaran, menurut sebagian sarjana, tidak selalu disebut syiqâq. ${ }^{13}$ Dikatakan syiqâq apabila alasan perceraian didasarkan pada fakta bahwa pertengkaran tersebut mengandung unsur-unsur yang membahayakan kehidupan suami isteri dan sudah terjadi pecahnya perkawinan (broken marriage). Apabila perceraian hanya didasarkan pada alasan perselisihan dan pertengkaran yang tidak mengandung unsur-unsur membahayakan dan belum sampai pada keadaan yang darurat, hal tersebut belum dapat dikatakan sebagai syiqâq. ${ }^{14}$ Dengan demikian, syiqâq adalah perselisihan antara suami isteri yang sangat

\footnotetext{
13 Abdul Manan, Penerapan Hukum Acara Perdata di Lingkungan Peradilan Agama (Jakarta: Prenada Media Goup, 2005) hlm. 387.

14 Ibid.
} 
memuncak serta jika perkawinan tetap dilanjutkan akan menimbulkan kemudharatan. 15

Aturan yang berkenaan dengan tata cara pemeriksaan perkara perceraian dengan alasan syiqâq diatur dalam penjelasan pasal 76 Undang-undang Nomor 7 Tahun 1989 yang menyatakan bahwa syiqâq adalah perselisihan yang tajam dan terus-menerus antara suami isteri. Hakikat syiqâq yang ada dalam pasal tersebut, memiliki makna yang sama jika dibandingkan dengan penjelasan pasal 39 ayat (2) huruf $f$ Undang-undang Nomor 1 Tahun 1974 jo. Pasal 19 huruf f Peraturan Pemerintah Nomor 9 Tahun 1975 memaknai syiqâq jika antara suami isteri terus menerus terjadi perselisihan dan pertengkaran dan tidak ada harapan akan hidup rukun lagi dalam rumah tangga. ${ }^{16}$ Akibatnya dalam pemeriksaan perkara syiqâq, selain harus tunduk pada aturan yang bersifat khusus, yakni pasal 76 Undang-Undang Nomor 7 Tahun 1989, juga harus mengikuti tata cara pemeriksaan sesuai dengan hukum acara perdata pada umumnya. ${ }^{17}$

Undang-undang Nomor 7 Tahun 1989 (yang telah mengalami perubahan dengan UU No. 3 Tahun 2006) tentang Peradilan Agama

15 Syiqâq dalam Islam dijelaskan dalam al-Qur'ân Surat al-Nisâ' (4): 35.

16 Syiqâq ternyata tidak jauh berbeda jika dibandingkan dengan alasan "perselisihan yang tidak didamaikan (onheelbare tweespalt)" sebagaimana yang diatur dalam pasal 52 sub 6 H.O.C.I yang berlaku bagi orang yang beragama Kristen Bumi Putera di Jawa dan Madura serta Karesidenan Manado, dan kemudian dengan Surat Edaran Menteri Dalam Negeri tanggal 28 Januari 1967, diberlakukan bagi semua warga negara yang beragama Kristen. Beberapa penyebab adanya onheelbare tweespalt tersebut antara lain masalah keuangan, perbedaan agama, pemeliharaan anak dan sebagainya.. Lihat R. Soetojo Prawirohamidjojo, Pluralisme Dalam PerundangUndangan Perkawinan di Indonesia (Surabaya : Airlangga University Press, 1986) hlm. 139

17 Dalam hukum terdapat azas lex specialis derogat lex generalis, yang berarti bahwa hukum yang bersifat khusus mengalahkan hukum yang bersifat umum. UndangUndang Perkawinan jo Peraturan Pemerintah Nomor 9 Tahun 1975 dapat dikategorikan sebagai peraturan yang bersifat umum (general), dengan dasar bahwa kedua peraturan perkawinan tersebut berlaku untuk semua golongan masyarakat tanpa membedakan agama, suku dan golongan. Sedangkan Undang-Undang Peradilan Agama merupakan peraturan yang bersifat khusus (spesialis). Hal ini nampak bahwa materi-materi yang diatur dalam undang-undang tersebut hanya meliputi orang yang beragama Islam (azas personalitas keislaman). Dalam perkara syiqâq semua peraturan hukum di atas dijadikan dasar pijakan karena dalam pasal 54 Undang-Undang Peradilan Agama menyatakan bahwa hukum acara yang berlaku di Peradilan Agama, tidak lain yang berlaku di Peradilan Umum. 
mengkategorikan syiqâq sebagai perkara yang dapat diajukan ke pengadilan agama sebagai perkara tersendiri. Konsekuensi, sejak pendaftaran di pengadilan, hal tersebut merupakan perkara syiqâq.

Dalam pemeriksaan perkara perceraian dengan alasan syiqâq haruslah memperhatikan beberapa, yaitu: Pertama, memeriksa keluarga atau orang dekat suami isteri. Pasal 76 ayat (1) Undangundang Nomor 7 Tahun 1989 menyatakan bahwa gugatan perceraian dengan alasan syiqâq, untuk mendapatkan putusan perceraian harus didengar keterangan saksi-saksi yang berasal dari keluarga atau orang-orang yang dekat dengan suami isteri. ${ }^{18}$ Dari isi pasal tersebut, tampak bahwa posisi keluarga atau orang dekat mempunyai peranan yang penting dan mutlak, karena apabila golongan orang-orang tersebut tidak didengar keterangannya, dapat menyebabkan batalnya putusan yang dijatuhkan.

Masalah yang dihadapi oleh hakim dalam memeriksa perkara syiqâq adalah kesulitan untuk menentukan keluarga yang paling dekat dan benar-benar mengetahui tentang problem rumah tangga yang dihadapi oleh suami isteri. Hal ini didasarkan bahwa tidak ada penjelasan yang rinci tentang siapakah yang disebut sebagai keluarga. ${ }^{19}$ Terlebih lagi, terdapat kesulitan tentang ukuran untuk menentukan tentang maksud dari orang-orang dekat. Ukuran dan kriteria kedekatan seseorang dengan orang lainnya sulit untuk diukur, terutama untuk mengukur seberapa dekat di antara mereka. Sehingga dapat terjadi menurut ukuran seseorang, A dekat dengan B, namun orang yang lain menilai bahwa A tidak dekat dengan $\mathrm{B}$.

Cara yang harus dilakukan oleh hakim untuk menilai kedekatan keluarga tersebut adalah dengan membuat daftar keluarga. Sebisa mungkin yang dihadirkan di depan sidang adalah golongan keluarga, karena pada umumnya mereka betul-betul mengetahui masalah suami isteri dan orang yang masih mempunyai

\footnotetext{
18 Afdol, Penerapan Hukum Waris, hlm. 199.

${ }_{19}$ Menurut penulis dalam hukum kekeluargaan dan kekerabatan di Indonesia, tidak ada ukuran yang pasti, siapakah yang disebut dengan keluarga. Namun pada umumnya orang masih dapat dikatakan mempunyai hubungan keluarga apabila ada hubungan darah ataupun hubungan perkawinan. Hal ini berbeda dengan istilah family dalam bahasa Inggris, yang diartikan sebagai "keluarga", yakni hanya meliputi suami, isteri dan anak-anaknya,
} 
hubungan keluarga akan melakukan berbagai upaya yang terbaik agar perkawinan suami isteri dapat diselamatkan.

Di lingkungan peradilan agama, tidak selamanya kerabat atau keluarga secara sukarela berkenan memberikan kesaksian. Hal ini disebabkan tidak semua keluarga mau terlibat dalam perselisihan suami isteri yang akan bercerai. Karena kesaksian keluarga dan orang dekat sifatnya imperatif, maka hakim secara ex officio dapat memerintahkan saksi yang bersangkutan dihadirkan secara paksa, jika ternyata tidak memenuhi panggilan pengadilan agama, padahal sudah dipanggil secara sah dan patut (Pasal 139 HIR atau pasal 165 R.Bg). ${ }^{20}$ Namun, walaupun dalam pasal 76 Undang-undang Nomor 7 Tahun 1989 peranan keluarga dan orang dekat dalam memberikan kesaksian sifatnya wajib, menurut yurisprudensi Mahkamah Agung, ketika terdapat kelalaian dari pengadilan di bawahnya, tidaklah secara otomatis menyebabkan kebatalan putusan perceraian tersebut, tetapi cukup memerintahkan pemeriksaan tambahan untuk memeriksa pihak keluarga atau orang-orang yang dekat dengan suami isteri.

Kedua, pengadilan dapat mengangkat hakam. Pasal 76 ayat (1) Undang-undang Nomor 7 Tahun 1989 menyatakan bahwa pengadilan setelah mendengar keterangan saksi tentang sifat persengketaan antara suami isteri dapat mengangkat seorang atau lebih dari keluarga masing-masing pihak ataupun orang lain untuk menjadi hakam. Menurut pasal 76 ayat (2), yang dimaksud dengan hakam adalah orang yang ditetapkan pengadilan dari pihak keluarga suami atau pihak keluarga isteri atau pihak lain untuk mencari upaya penyelesaian perselisihan terhadap syiqâq. ${ }^{21}$

Keberadaan hakam dalam perkara syiqâq adalah bersifat fakultatif, dan tidak bersifat imperatif. Akibatnya, di pengadilan agama, hakam tidak selalu ada dalam perkara syiqâq. Yang terjadi, walaupun diangkat sebagai hakam, terkadang hanyalah sekedar memenuhi formalitas undang-undang saja dan seringkali majelis hakim hanya mencukupkan kesaksian dari keluarga. Dalam praktiknya, jarang majelis hakim di pengadilan agama mengangkat

\footnotetext{
${ }^{20}$ M. Yahya Harahap, Kedudukan kewenangan dan Acara Peradilan Agama (Jakarta : Sinar Grafika, 2001) hlm. 245.

${ }^{21}$ Afdol, Penerapan Hukum Waris, hlm. 194.
} 
hakam, karena dengan adanya hakam akan menyebabkan proses pemeriksaan dan persidangan berlarut-larut, sehingga perkara perceraian di pengadilan agama akan bertumpuk. Ketika ditunjuk seorang atau beberapa hakam, upaya penyelesaian perselisihan akan semakin kacau karena semakin banyaknya orang yang ikut campur.

Hakam dalam hukum acara bersifat insidentil dari hakim sebelum memutuskan putusan akhir. Wujud dari putusannya adalah berupa putusan sela, yang menyatakan bahwa persidangan ditunda selama jangka waktu tertentu, di mana dalam jangka waktu tersebut hakam yang berupaya menyelesaikan perselisihan terhadap syiqâq tersebut.

Setelah jangka waktu yang diberikan oleh majelis hakim kepada hakam usai, maka hasil arbitrase seorang hakam akan dikembalikan kepada majelis hakim. Hal ini menunjukan bahwa hakam tidaklah mengikat hakim. Hakam hanya berwenang mengusulkan atau memberikan pendapat. Hal ini tentu saja sesuai dengan azas kebebasan hakim dalam memeriksa dan memutus perkara. ${ }^{22}$

\section{Peranan Hakim dalam Memeriksa dan Memutus Perkara Syiqâq}

Peradilan agama merupakan salah satu wadah bagi umat Muslim yang mencari keadilan sesuai dengan ketentuan syarî́at Islam. Harapan memperoleh keadilan tersebut sangat bergantung pada kemampuan dan hati nurani hakim. Dalam menjalankan fungsi peradilan, hakim harus menyadari sepenuhnya bahwa tugas pokok hakim adalah menegakan hukum dan keadilan.

Pasal 62 Undang-undang Nomor 7 Tahun 1989 jo. pasal 25 ayat (1) Undang-Undang Nomor 4 Tahun 2004 menyatakan bahwa segala putusan pengadilan selain harus memuat alasan-alasan dan dasardasar putusan juga harus memuat pula pasal-pasal tertentu dari peraturan-peraturan yang bersangkutan atau sumber hukum tak tertulis yang dijadikan dasar untuk mengadili.23 Dari kedua pasal tersebut, ada 2 (dua) hal yang harus diperhatikan oleh hakim dalam memeriksa dan memutus perkara, termasuk perkara perceraian

\footnotetext{
22 Yang termasuk dalam pengertian kebebasan hakim adalah bebas dari campur tangan kekuasaan Negara yang lain, hakim bebas dari paksaan oleh kekuatan di luar pengadilan dan bebas dalam menerapkan dan menafsirkan hukum.

23 Undang-undang Nomor 4 dan 5 Tahun 2004 tentang Kekuasaan Kehakiman dan Mahkamah Agung (Bandung: Fokusmedia, 2004), hlm. 10.
} 
dengan alasan perselisihan dan pertengkaran (syiqâq), yakni selain putusan itu harus disertai dengan alasan dan dasar, juga harus pula memuat pasal-pasal atau sumber hukum tidak tertulis.

Dalam perkara syiqâq hakim harus cermat dalam memeriksa fakta-fakta selama persidangan, terutama dalam menilai apakah perselisihan dan pertengkaran tersebut benar-benar tidak dapat didamaikan lagi. Sebab alasan tersebut sangat mudah untuk dijadikan dasar perceraian. Hakim harus menguji alasan dari pihak yang memohon cerai, karena alasan perselisihan dan pertengkaran bukanlah suatu alasan langsung untuk putusnya perkawinan, namun hanya merupakan suatu kualifikasi dari berbagai bentuk keadaan yang menyebabkan timbulnya perselisihan dan pertengkaran. Karena hakim wajib mencantumkan pertimbangan yang cukup dan matang dalam setiap keputusan. ${ }^{24}$

Sebagai gambaran, misalnya, seorang suami berkeinginan menceraikan isterinya dengan alasan rumah tangga mereka tidak pernah bisa rukun. Dalil atau alasan yang diajukan oleh suami dalam gugatannya adalah bahwa rumah tangganya sudah tidak dapat dipertahankan lagi karena sering bertengkar. Selain dalil pada tahap pembuktian, hakim haruslah membebankan kepada suami untuk menguraikan fakta-fakta tentang penyebab sering bertengkar, misalnya isteri sering melalaikan kewaibannya sebagai ibu rumah tangga, karena sering keluar rumah tanpa pamit kepada suami.

Selain itu hakim idealnya dalam memeriksa perceraian dengan alasan syiqâq, mempertimbangkan perlu atau tidaknya mengangkat hakam. Apabila pada tahap awal pemeriksaan, hakim menilai suami isteri masih dapat dipersatukan, karena ternyata alasan perceraian sangat sepele, sangatlah terpuji dan akan bermanfaat jika hakim mengangkat hakam. Selama ini hakim jarang mengangkat hakam, dengan alasan pengangkatan hakam akan menyebabkan proses pernyelesaian bertele-tele. Hal ini dilandasi, bahwa pengadilan agama dalam memeriksa perkara dapat dikategorikan sebagai 'kejar tayang', dengan tujuan agar perkara tidak menumpuk.

Namun yang sering dilupakan adalah sisi positif dari pengangkatan hakam. Sebenarnya dalam pasal 65 dan 82 Undang-

${ }^{24}$ Harahap, Kedudukan, kewenangan dan Acara Peradilan Agama, hlm. 313. 
undang Nomor 7 Tahun 1989 terkandung azas wajib mendamaikan. ${ }^{25}$ Azas kewajiban hakim untuk mendamaikan pihak-pihak yang bersengketa bisa berupa anjuran, nasihat, atau penjelasan. ${ }^{26}$ Keberadaan hakam dalam proses perdamaian memang akan lebih panjang, namun kemungkinan kembali bersatu lebih terbuka lebar, sehingga proses perdamaian ada peluang untuk berhasil. Hal tersebut akan lebih memberikan kemanfaatan kepada pasangan suami isteri yang hendak bercerai.

\section{Penutup}

Hakim pengadilan agama dalam menyelesaikan perkara perceraian dengan alasan terus menerus terjadi perselisihan dan pertengkaran sehingga tidak ada harapan lagi untuk hidup rukun (syiqâq) hendaknya arif dan cermat, terutama dalam menilai latar belakang perselisihan dan pertengkaran tersebut.

Idealnya, hakim dalam menangani perkara perceraian dengan alasan di atas, pada kasus-kasus tertentu, harus mengangkat hakam. Keberadaan hakam tersebut diharapkan dapat memulihkan hubungan suami isteri. Jika hal tersebut tercapai, maka keutuhan ikatan perkawinan dapat terselamatkan. Wallâh a'lam bi al-shawâb.

\section{Daftar Pustaka}

Harahap, M. Yahya. Kedudukan kewenangan dan Acara Peradilan Agama. Jakarta: Sinar Grafika, 2001

Lubis, Sulaikin dan Marzuki, Wismar 'Ain. Hukum Acara Perdata Peradilan Agama di Indonesia. Jakarta: Prenada Media Group, 2005

Manan, Abdul. Penerapan Hukum Acara perdata di Lingkungan Peradilan Agama. Jakarta: Prenada Media Goup, 2005

Musawamah, Siti dan Hasan, Moh. Cerai Gugat di Pengadilan Agama. Penelitian Kolektif, STAIN Pamekasan, 2005.

\footnotetext{
25 Afdol, Penerapan Hukum Waris, hlm. 189 dan 195.

26 Sulaikin Lubis dan Wismar 'Ain Marzuki, Hukum Acara Perdata Peradilan Agama di Indonesia (Jakarta : Prenada Media Group, 2005), hlm. 63.
} 
Nuruddin, Amir dan Tarigan, Azhari Akmal. Hukum Perdata Islam di Indonesia. Jakarta: Prenada Media, 2004

Prawirohamidjojo, R. Soetojo. Pluralisme dalam Perundang-Undangan Perkawinan di Indonesia. Surabaya: Airlangga University Press, 1986

Salim. Pengantar Hukum Perdata Tertulis (BW). Jakarta: Sinar Grafika, 2005

Subekti. Pokok-Pokok Hukum Perdata. Jakarta: Intermasa, 1995

Vollmar. Pengantar Studi Hukum Perdata. Jakarta: RajaGrafindo Persada, 1996 